\title{
Protective effects of taurine against inflammation, apoptosis, and oxidative stress in brain injury
}

\author{
XIAOLI NIU, SIMIN ZHENG, HONGTAO LIU and SIYUAN LI
}

Department of Anesthesiology, The Second Affiliated Hospital of Xi'an Jiaotong University, Xi'an, Shaanxi 710004, P.R. China

Received March 22, 2018; Accepted August 28, 2018

DOI: $10.3892 / \mathrm{mmr} .2018 .9465$

\begin{abstract}
The protective effect of taurine against inflammation, apoptosis and oxidative stress in traumatic brain injury was investigated in the present study. Taurine is a non-proteogenic and essential amino acid in animals. It plays a critical nutritional role in brain cell growth, differentiation, and development. Taurine is involved in regeneration and neuroprotection in the injured nervous system, and is an effective antioxidant against lead-, cadmium-, and exercise-induced oxidative stress. Astrocytes and neuron cells were co-cultured and cells were treated with different concentrations of taurine (100, 200 and $300 \mathrm{mg} / \mathrm{l})$ for $72 \mathrm{~h}$, and the levels of reactive oxygen species, malondialdehyde, reduced glutathione, glutathione peroxidase, superoxide dismutase, catalase, acetylcholinesterase, tumor necrosis factor- $\alpha$, interleukin- 6 , caspase-3, p53, B-cell lymphoma 2 and Bcl-2-associated $\mathrm{X}$ protein were determined. These inflammatory, apoptotic, and oxidative stress markers were substantially increased in injured cells, and returned to normal levels following taurine supplementation. Thus, taurine supplementation may be effective against oxidative stress, apoptosis, and inflammation in injured brain cells.
\end{abstract}

\section{Introduction}

Taurine is a non-proteogenic and essential amino acid in animals (1), and is known to play a critical nutritional role in brain cell growth, differentiation, and development (2). Huxtable (3) have reported on the functional role of taurine in the central nervous system, as well as its functions in cardiovascular and skeletal muscle. Rak et al (4) demonstrated that taurine plays a key role in regeneration and neuroprotection in the injured nervous system. Taurine is an effective antioxidant against lead-, cadmium-, and exercise-induced oxidative stress (5), and is known to reduce the secretion of lipids and

Correspondence to: Dr Siyuan Li, Department of Anesthesiology, The Second Affiliated Hospital of Xi'an Jiaotong University, 157 of West 5th Road, Xi'an, Shaanxi 710004, P.R. China

E-mail: lowesiomew@yahoo.com

Key words: apoptosis, brain injury, inflammation, neurons, taurine apolipoprotein B100 in liver cancer cells (6). Taurine is also invovled in neurotransmission, detoxification, osmoregulation, calcium homeostasis, obesity prevention, excitotoxicity, osmotic shock recovery, and prevention of seizures (7-13).

Traumatic brain injury (TBI) leads to cognitive deficits, high mortality, and impaired movement (14). The most common cause of TBI is external force to the brain, and it can be classified as closed or penetrating head injury (15). Ischemia, oxidative stress, apoptosis, inflammation, excitotoxicity, and vascular and neuronal damage may also cause TBI $(16,17)$. Lotocki et al (18) reported that inflammation is a well-known critical event in TBI, which may be mediated by the secretion of cytokines and activation of glial cells. Taurine supplementation may substantially reduce inflammatory cytokines, such as tumor necrosis factor (TNF)- $\alpha$, interleukin (IL)-6, and IL-1 $\beta$, in spinal cord injury (19). Heidari et al (20) reported a protective effect of taurine against acute and chronic liver injuries. Recently, Wang et al (2) investigated the protective role of taurine against TBI. In the present study, we investigated the therapeutic effect of taurine on levels of ROS, malondialdehyde (MDA), reduced glutathione (GSH), glutathione peroxidase (Gpx), superoxide dismutase (SOD), catalase, acetylcholinesterase (AChE), TNF- $\alpha$, IL-6, caspase-3, p53, bcl-2 and bax in injured brain cells.

\section{Materials and methods}

Animals. Twenty-four male albino Wistar strain neonatal rats were obtained from The Second Affiliated Hospital of Xi'an Jiaotong University (Xi'an, China). The rats weighed 5-10 g and were allowed free access to water and food with a 12-h light and dark cycle. Rats were sacrificed by decapitation following intraperitoneal administration of ketamine hydrochloride $(80 \mathrm{mg} / \mathrm{kg})$ and xylazine $(10 \mathrm{mg} / \mathrm{kg})$. All experiments involving rats were monitored and approved by the ethics committee of The Second Affiliated Hospital of Xi'an Jiaotong University (Ref no. 2o14/2Tx1221).

Cell culture. Cortical tissues were isolated from embryonic day 15 rats and disassociated. Separated cells were cultured at a density of $1.5 \times 10^{3}$ cells $/ \mathrm{ml}$ on existing astrocyte cell cultures. Co-cultures of astrocytes and neuron cells were prepared as previously described (21). The co-culture was supplemented with standard growth medium containing $10 \%$ fetal bovine serum and Dulbecco's modified Eagle's medium. 
Experimental traumatic brain cell injury model. Experimental traumatic brain cell injury was induced according to Katano et al (22). Traumatic model cells were supplemented with G5 (2\%) for $12 \mathrm{~h}$ before the induction of injury. The mechanical injury was induced using a standard scratch method (23), and standard scratches were made in 6-well plates. Cells were supplemented with standard growth medium. After $24 \mathrm{~h}$, cell survival was evaluated as lactate dehydrogenase activity (ab102526; Abcam, Cambridge, UK).

Taurine treatment and sample collection. Cells were treated with 100, 200, or $300 \mathrm{mg} / \mathrm{l}$ of taurine (ab141063; Abcam) for $72 \mathrm{~h}$. Following treatment, the medium was removed carefully and the cells were washed with phosphate buffered saline. The cells were collected, centrifuged, and stored at $-80^{\circ} \mathrm{C}$.

Oxidative markers. ROS level was measured by the incubation of cells with dichloro-dihydro-fluorescein diacetate (DCFH-DA) for $30 \mathrm{~min}$, and fluorescence was measured under a fluorescence plate reader (24). The MDA content in the cell supernatant was determined by measuring thiobarbituric acid reactive species (TBARS). Briefly, the reaction tube contained $0.1 \mathrm{ml}$ of cell culture supernatant, thiobarbituric acid $(1.5 \mathrm{ml})$, $0.2 \mathrm{ml}$ of sodium dodecyl sulfate (SDS), and acetic acid $(1.5 \mathrm{ml})$. The resultant upper layer product was measured at $534 \mathrm{~nm}$ (24). GSH levels were determined based on Ellman's reaction. The absorbance was measured at $412 \mathrm{~nm}$ (24). Gpx activity was measured by adding $0.2 \mathrm{ml}$ of Tris- $\mathrm{HCl}$ buffer, $0.2 \mathrm{ml}$ of GSH, $0.1 \mathrm{ml}$ of $\mathrm{H}_{2} \mathrm{O}_{2}, 0.2 \mathrm{ml}$ of homogenate, and sodium azide $(0.1 \mathrm{ml})$ to the reaction tube. The reaction tube was centrifuged for $10 \mathrm{~min}$ at $3,000 \mathrm{x} \mathrm{g}$. Then, cell culture supernatant $(0.2 \mathrm{ml})$ and Ellman's reagent $(0.1 \mathrm{ml})$ were added to the reaction tube, and the final absorbance was measured at $340 \mathrm{~nm} \mathrm{(25).}$

SOD activity was determined by adding cell culture supernatant $(0.1 \mathrm{ml})$, nitro blue tetrazolium $(0.3 \mathrm{ml}), \mathrm{NADH}(0.2 \mathrm{ml})$ and sodium phosphate buffer $(1.2 \mathrm{ml})$. The final absorbance was measured at $560 \mathrm{~nm}$ (25). Catalase activity was determined by adding phosphate buffer $(500 \mu \mathrm{l})$, cell culture supernatant (500 $\mu \mathrm{l})$ and $\mathrm{H}_{2} \mathrm{O}_{2}(500 \mu \mathrm{l})$. Then, $\mathrm{TiOSO}_{4}(500 \mu \mathrm{l})$ was added to the reaction tube, and the final absorbance was measured at $420 \mathrm{~nm}$ (25). AChE activity was determined by the addition of acetylcholine $(0.02 \mathrm{ml})$, cell culture supernatant $(0.02 \mathrm{ml})$, DTNB $(0.1 \mathrm{ml})$ and phosphate buffer $(3 \mathrm{ml})$ into the reaction tube. The final absorbance was measured at $410 \mathrm{~nm}$ (26).

Inflammatory markers. TNF- $\alpha$ and IL-6 levels were determined in the cell culture were determined by enzyme-linked immunosorbent assay (RAB0141-1KT, Mouse ELISA kit; Sigma-Aldrich China, Inc., Shanghai, China) (27-29).

Apoptosis markers. For the reverse transcription-quantitative polymerase chain reaction (RT-qPCR) assay, RNA was isolated from the cells and converted into cDNA using oligo (dT) primers. Then, qPCR was used to quantify the mRNA expression with primers specific for caspase-3, p53, bcl-2 and bax (Table I). Glyceraldehyde 3-phosphate dehydrogenase (GAPDH) was used as a qPCR internal control. The $2^{-\Delta \Delta C q}$ method was used to calculate the relative ratios of expression (30). Caspase-3 protein expression was determined by immunofluorescence staining according to Lobos et al (31) and images were taken under fluorescence microscope (IX73 Inverted Microscope; Olympus Corporation, Tokyo, Japan).

Statistical analysis. Values are given as mean with standard deviations. Differences between the control and taurine groups were evaluated using the unpaired Student's t-test. One-way ANOVA was applied for statistical analysis of data and post hoc Tukey's test was used for multiple comparisons. $\mathrm{P}<0.05$ was considered to indicate a statistically significant difference.

\section{Results}

Effect of taurine on oxidative markers. The protective effect of taurine against inflammation, apoptosis, and oxidative stress in TBI was investigated in this study. Intracellular ROS levels were substantially increased to 234.52 relative fluorescence units (RFU) in injured brain cells. However, taurine supplementation significantly reduced ROS levels to 191.1 (100 mg/l), 135.24 (200 mg/l), and 44.72 RFU (300 mg/l) in injured brain cells $(\mathrm{P}<0.05$; Fig. 1). Lipid peroxidation was substantially increased to $155.32 \mathrm{nmol} / \mathrm{g}$ in injured brain cells. Taurine supplementation significantly reduced lipid peroxidation to $131.87(100 \mathrm{mg} / \mathrm{l}), 94.61(200 \mathrm{mg} / \mathrm{l})$, and $47.3 \mathrm{nmol} / \mathrm{g}$ (300 mg/l) in injured brain cells $(\mathrm{P}<0.05$; Fig. 2$)$. GSH content was substantially reduced to $29.25 \mathrm{mg} / \mathrm{g}$ in injured brain cells, while taurine supplementation significantly increased GSH content to 44.46 (100 mg/l), $62.63(200 \mathrm{mg} / \mathrm{l})$, and $83.56 \mathrm{mg} / \mathrm{g}$ $(300 \mathrm{mg} / \mathrm{l})$ in injured brain cells $(\mathrm{P}<0.05$; Fig. 2$)$.

SOD activity was substantially reduced to $2.7 \mathrm{U} / \mathrm{mg}$ in injured brain cells. Taurine supplementation significantly increased SOD activity to $3.3(100 \mathrm{mg} / \mathrm{l}), 4.5(200 \mathrm{mg} / \mathrm{l})$, and $5.1 \mathrm{U} / \mathrm{mg}(300 \mathrm{mg} / \mathrm{l})$ in injured brain cells $(\mathrm{P}<0.05$; Fig. 3$)$. Catalase activity was substantially reduced to $4.7 \mathrm{U} / \mathrm{g}$ in injured brain cells. Taurine supplementation significantly increased catalase activity to $6.2(100 \mathrm{mg} / \mathrm{l}), 8.9(200 \mathrm{mg} / \mathrm{l})$, and $10.6 \mathrm{U} / \mathrm{g}(300 \mathrm{mg} / \mathrm{l})$ in injured brain cells $(\mathrm{P}<0.05$; Fig. 3$)$. Gpx activity was substantially reduced to $0.34 \mathrm{mg} /$ protein in injured brain cells. Taurine supplementation significantly increased Gpx activity to 0.49 (100 mg/l), $0.62(200 \mathrm{mg} / \mathrm{l})$, and $0.84 \mathrm{mg} /$ protein $(300 \mathrm{mg} / \mathrm{l})$ in injured brain cells $(\mathrm{P}<0.05$; Fig. 4). AChE activity was substantially reduced to $4.1 \mu \mathrm{mol} / \mathrm{min} / \mathrm{mg}$ of protein in injured brain cells. Taurine supplementation significantly increased AChE activity to 6.2 (100 mg/l), $8.4(200 \mathrm{mg} / \mathrm{l})$, and $10.9 \mu \mathrm{mol} / \mathrm{min} / \mathrm{mg}$ of protein $(300 \mathrm{mg} / \mathrm{l})$ in injured brain cells $(\mathrm{P}<0.05$; Fig. 4).

Effect of taurine on inflammatory markers. TNF- $\alpha$ and IL-6 levels were substantially reduced to 437.12 and $301.5 \mathrm{pg} / \mathrm{mg}$ of protein, respectively, in injured brain cells. Following taurine treatment, TNF- $\alpha$ levels were decreased [362.11 (100 mg/l), $287.45(200 \mathrm{mg} / \mathrm{l})$, and $127.25 \mathrm{pg} / \mathrm{mg}$ of protein $(300 \mathrm{mg} / \mathrm{l})]$, while IL-6 levels were increased [245.6 (100 mg/l), 186.5 (200 mg/l), and $87.5 \mathrm{pg} / \mathrm{mg}$ of protein $(300 \mathrm{mg} / \mathrm{l})]$ in injured brain cells $(\mathrm{P}<0.05$; Fig. 5$)$.

Effect of taurine on apoptosis markers. Taurine supplementation significantly reduced p53, caspase-3, and bax mRNA expression and increased bcl-2 mRNA expression in injured brain cells $(\mathrm{P}<0.05$; Fig. 6). Protein expression of caspase- 3 
Table I. List of primers used in RT-qPCR for mRNA expression of p53, caspase-3, bax and Bcl-2.

\begin{tabular}{lll}
\hline Gene name & \multicolumn{2}{c}{ Sense primer } \\
\hline p53 & 5'-TAACAGTTCCTGCATGGGCGGC-3' & Anti-sense primer \\
Caspase-3 & 5'-TTAATAAAGGTATCCATGGAGAACACT-3' & 5'-AGGACAGGCACAAACACGCACC-3' \\
Bax & 5'-TGGAGCTGCAGAGGATGATTG-3' & 5'-GAAGTTGCCGTCAGAAAACATG-3' \\
GAPDH & 5'-TCCCTCAAGATTGTCAGCAA-3' & 5'-AGATCCACAACGGATACATT-3' \\
Bcl-2 & 5'-CACCCCTGGCATCTTCTCCTT-3' & 5'-AGCGTCTTCAGAGACAGCCAG-3'
\end{tabular}

Bcl-2, B-cell lymphoma 2; Bax, Bcl-2-associated X protein; RT-qPCR, reverse transcription-quantitative polymerase chain reaction.
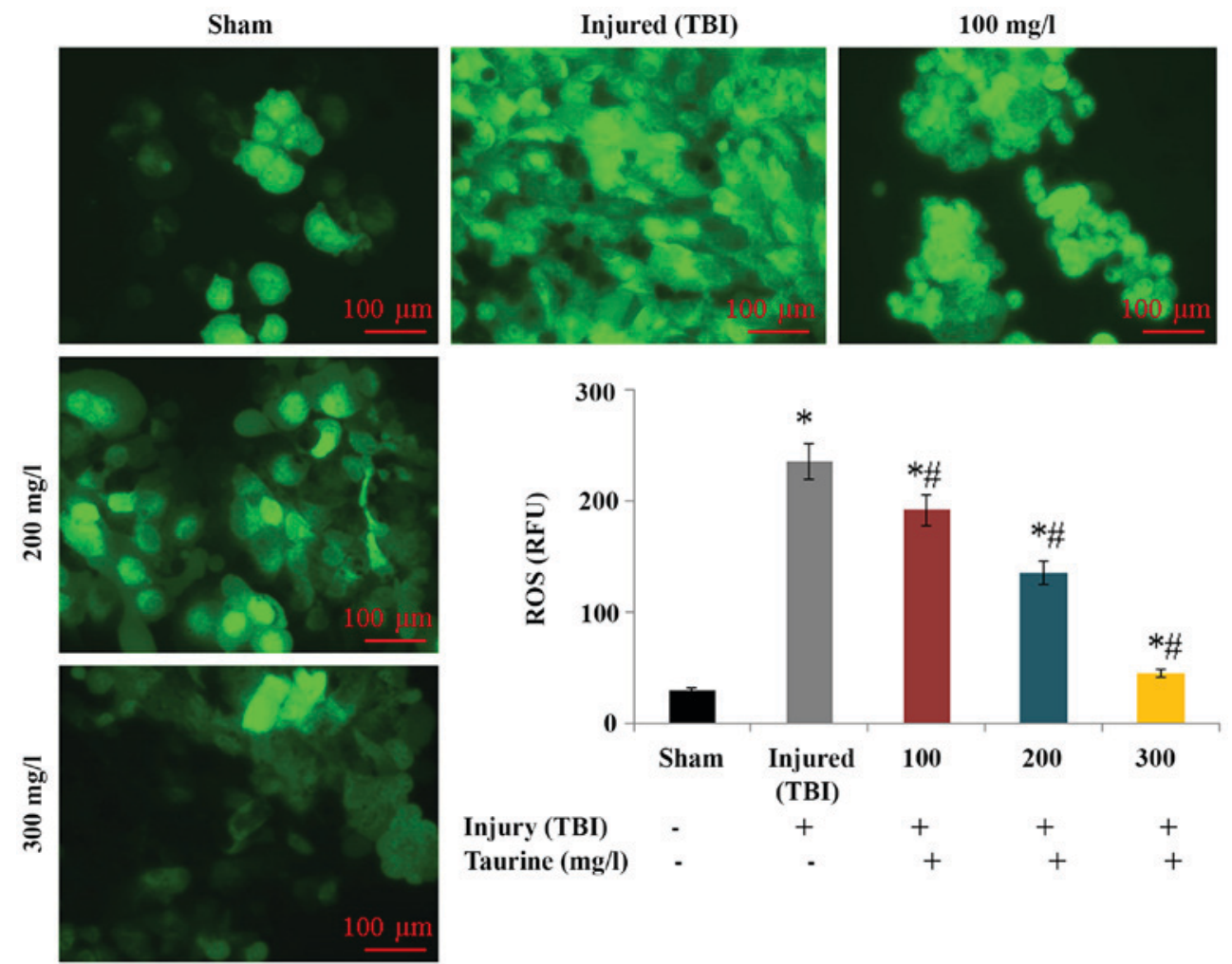

Figure 1. Effect of taurine supplementation on intracellular reactive oxygen species in injured brain cells. Data are expressed as mean \pm standard deviation. ${ }^{*} \mathrm{P}<0.05$ vs. sham and ${ }^{*} \mathrm{P}<0.05$ vs. injured (TBI). Magnification, $\mathrm{x} 40$. The scale bar is $100 \mu \mathrm{m}$. TBI, traumatic brain injury.
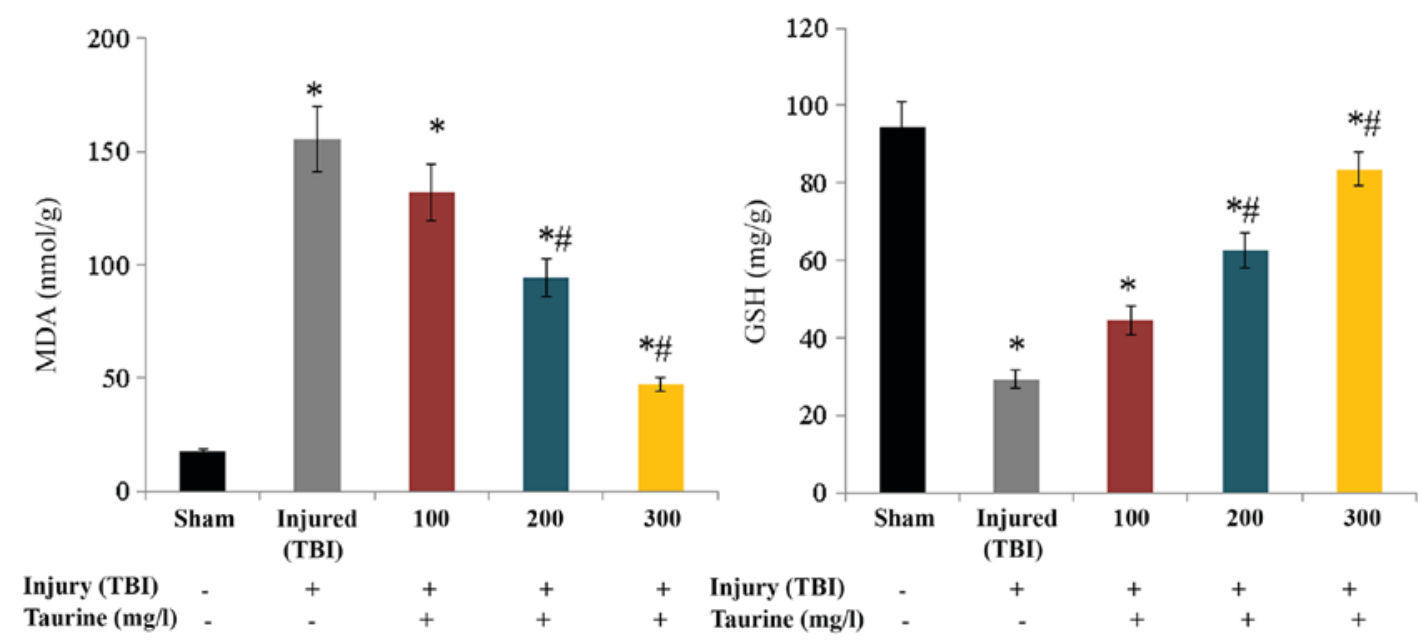

Figure 2. Effect of taurine supplementation on lipid peroxidation and reduced GSH levels in injured brain cells. Data are expressed as mean \pm standard deviation. ${ }^{*} \mathrm{P}<0.05$ vs. sham and ${ }^{\#} \mathrm{P}<0.05$ vs. injured (TBI). TBI, traumatic brain injury; MDA, malondialdehyde; GSH, glutathione. 

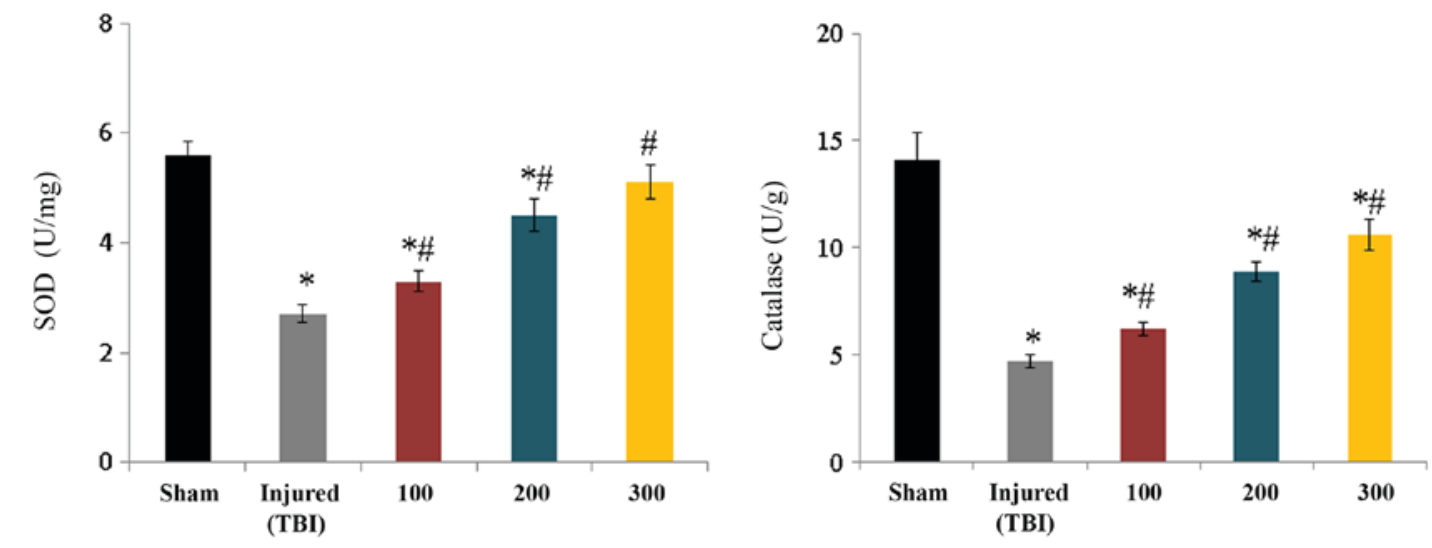

$\begin{array}{lllllllllll}\text { Injury (TBI) } & - & + & + & + & + & \text { Injury (TBI) } & - & + & + & + \\ \text { Taurine }(\mathrm{mg} / \mathrm{l}) & - & - & + & + & + & \text { Taurine }(\mathrm{mg} / \mathrm{l}) & - & - & + & + \\ +\end{array}$

Figure 3. Effect of taurine supplementation on SOD and catalase activity in injured brain cells. Data are expressed as mean \pm standard deviation. "P $<0.05$ vs. sham and ${ }^{\#} \mathrm{P}<0.05$ vs. injured (TBI). TBI, traumatic brain injury; SOD, superoxide dismutase.
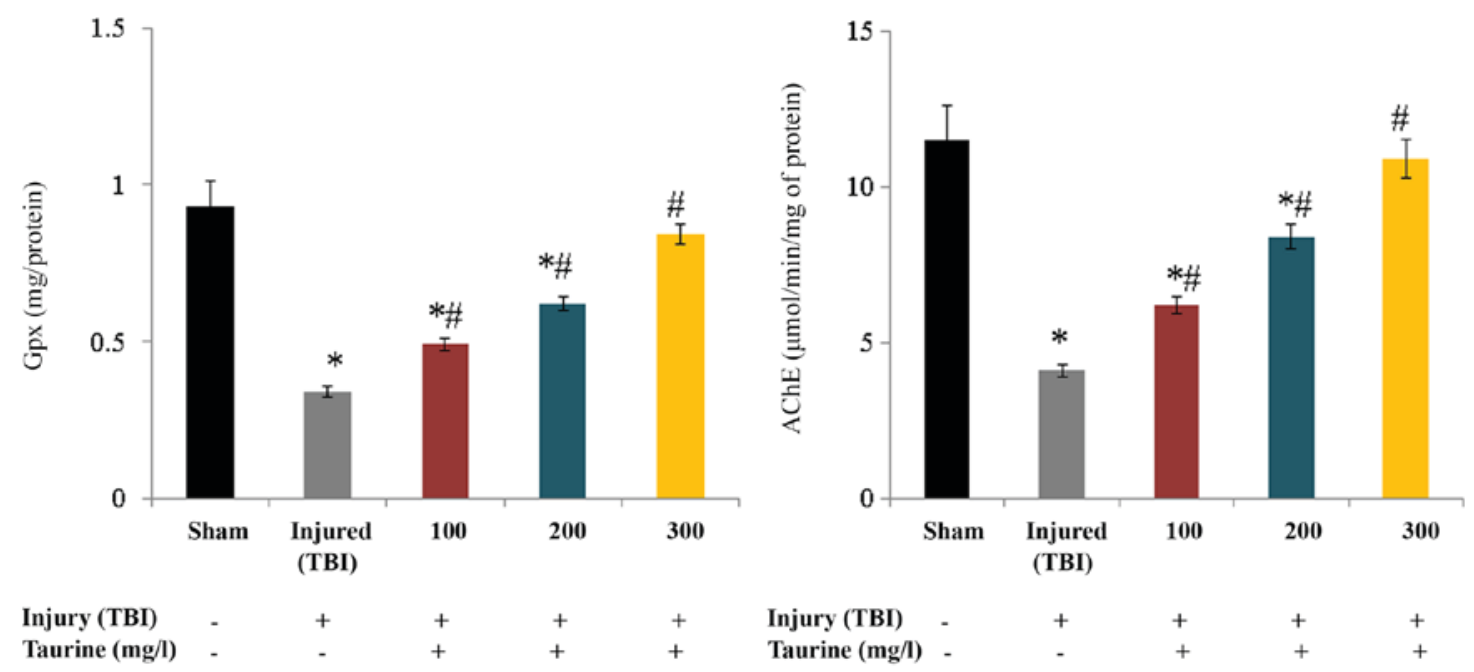

Figure 4. Effect of taurine supplementation on Gpx and AChE activity in injured brain cells. Data are expressed as mean \pm standard deviation. ${ }^{*}<0.05$ vs. sham and ${ }^{\#} \mathrm{P}<0.05$ vs. injured (TBI). TBI, traumatic brain injury; Gpx, glutathione peroxidase; AChE, acetylcholinesterase.

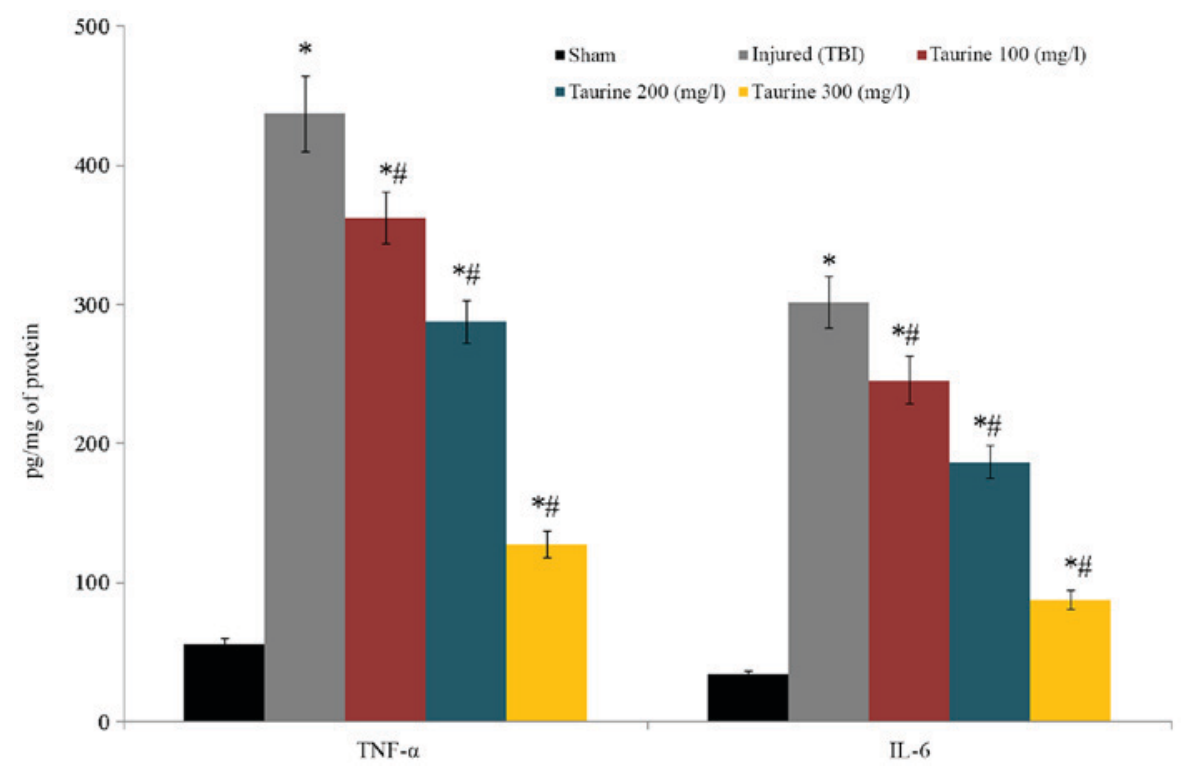

Figure 5. Effect of taurine supplementation on TNF- $\alpha$ and IL-6 levels in injured brain cells. Data are expressed as mean \pm standard deviation. ${ }^{*} \mathrm{P}<0.05$ vs. sham and ${ }^{\#} \mathrm{P}<0.05$ vs. injured (TBI). TBI, traumatic brain injury; TNF, tumor necrosis factor; IL, interleukin. 


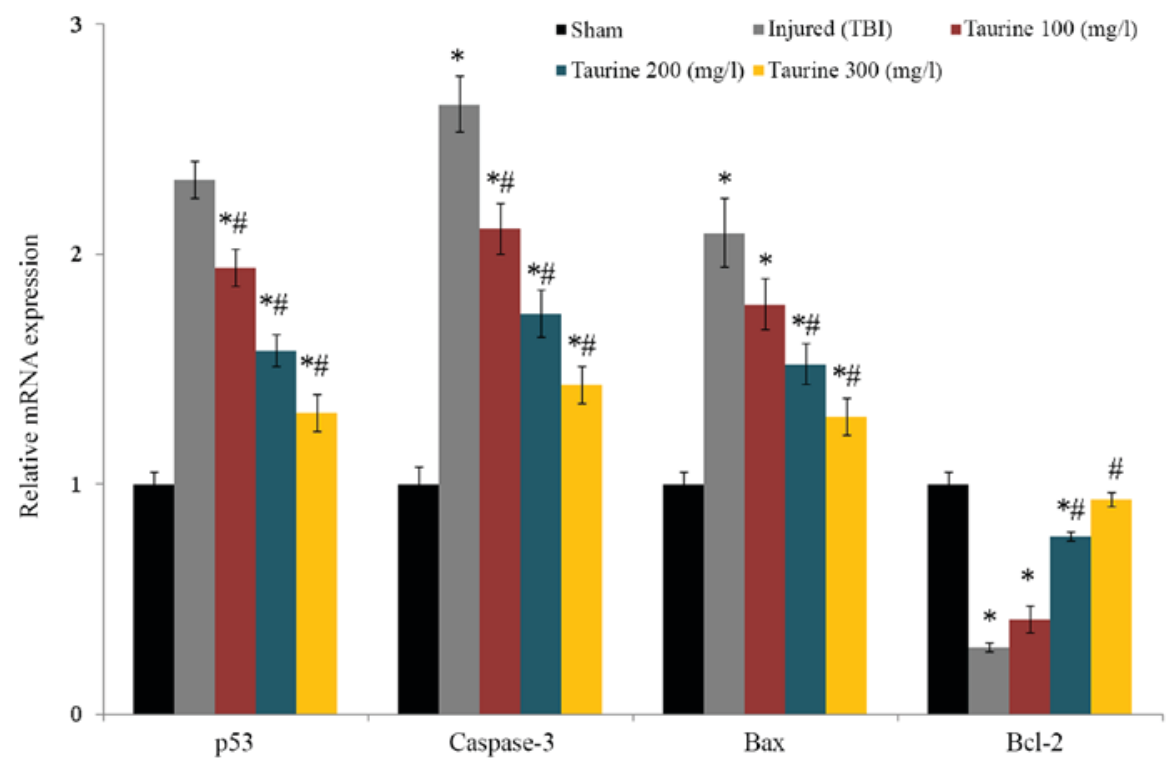

Figure 6. Effect of taurine supplementation on mRNA expression of p53, caspase-3, bax, and Bcl-2 in injured brain cells. Data are expressed as mean \pm standard deviation. ${ }^{*} \mathrm{P}<0.05$ vs. sham and ${ }^{\#} \mathrm{P}<0.05$ vs. injured (TBI). TBI, traumatic brain injury; Bax, Bcl-2-associated $\mathrm{X}$ protein; Bcl-2, B-cell lymphoma 2.
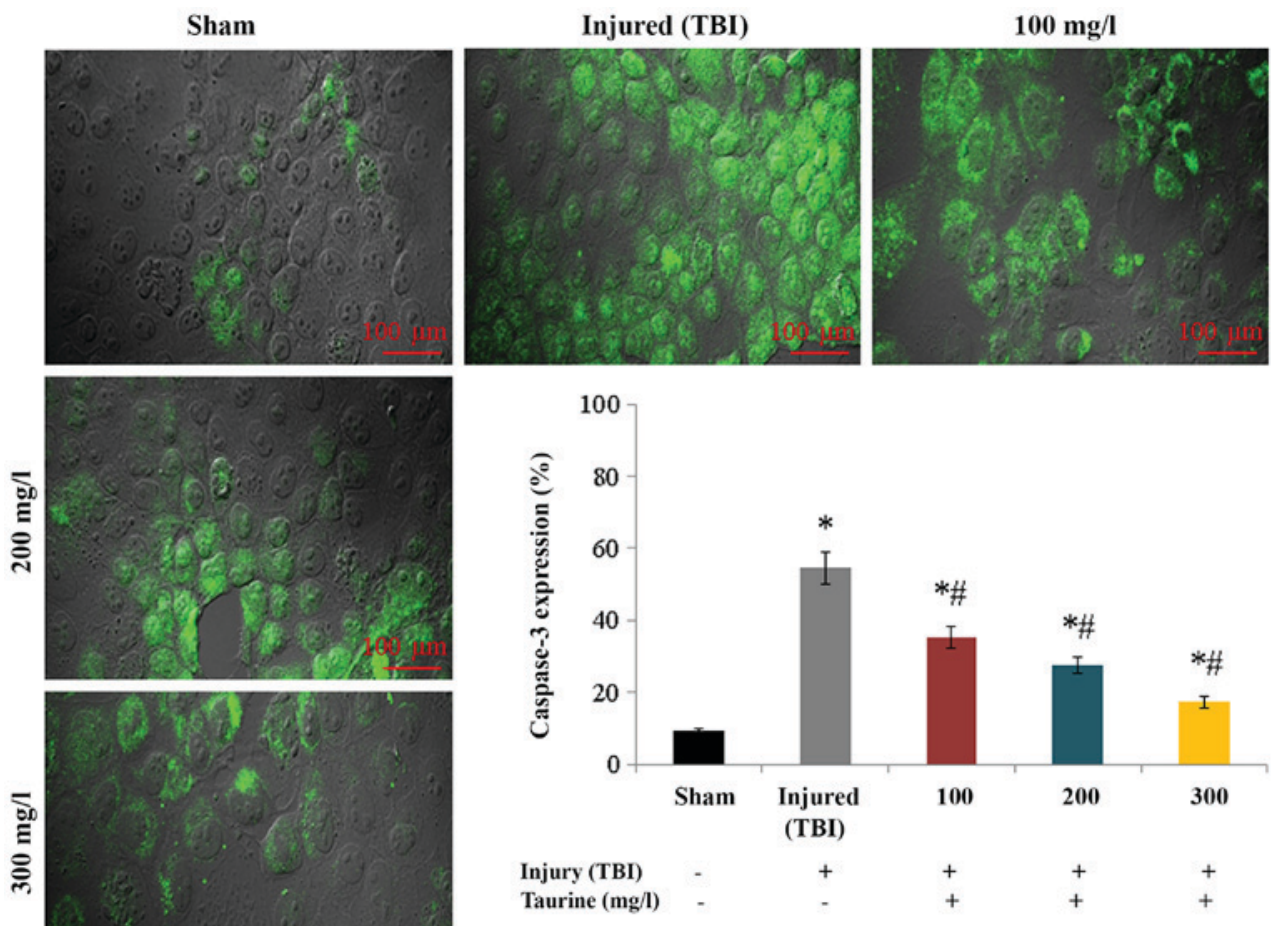

Figure 7. Effect of taurine supplementation on protein expression of caspase- 3 in injured brain cells. Data are expressed as mean \pm standard deviation. ${ }^{*} \mathrm{P}<0.05$ vs. sham and ${ }^{\#} \mathrm{P}<0.05$ vs. injured (TBI). Magnification, $\mathrm{x} 40$. The scale bar is $100 \mu \mathrm{m}$. TBI, traumatic brain injury

increased to $54.51 \%$ in injured brain cells compared to normal brain cells. Taurine supplementation substantially reduced caspase-3 protein expression to 35.31 (100 mg/l), 27.48 (200 mg/l), and 17.3\% (300 mg/l) $(\mathrm{P}<0.05$; Fig. 7).

\section{Discussion}

This study investigated the protective effect of taurine against inflammation, apoptosis, and oxidative stress in TBI.
Taurine supplementation has been shown to substantially reduce infarct volume, brain swelling, cell death, and neurological deficits in a stroke-induced rat model (32). Taurine also significantly reduced apoptosis in cardiomyocytes of rats (33). Sun et al (34) also reported a protective effect of taurine against head injury. Several researchers have associated mitochondrial dysfunction with increased ROS and superoxide production, glutathione oxidation, and reduced antioxidant enzymes (2). 
Taurine increases antioxidant activity by reducing superoxide production, which leads to improved mitochondrial function (35). Taurine also plays a crucial role in protein synthesis in mitochondria, and increases electron transport chain (ETC) activity (36). Our experimental results indicate that taurine increases antioxidant levels through increased mitochondrial ETC activity in TBI.

Mitochondrial dysfunction leads to increased production of oxidants, which leads to neuronal apoptosis and necrosis. Mitochondrial respiratory chains present on the inner mitochondrial membrane contain four transmembrane protein complexes. Chen and Chan (37) observed energy metabolism dysfunction associated with pathological changes in mitochondria following TBI. Several researchers have found that respiratory enzyme levels were decreased following traumatic and ischemic brain injury $(38,39)$. Zhu et al $(40)$ have illustrated the incidence of gastrointestinal dysfunction in TBI. Mitochondrial dysfunction can increase the production of oxidants, which play a crucial role in apoptosis and necrosis of neurons. Proapoptotic markers, such as bcl-2, increase in response to increased oxidants produced in brain injury. Apoptosis is induced through increased oxidants and misfolded proteins (41). Increased production of reactive oxygen species (ROS) and superoxide, glutathione oxidation, and reduced antioxidant enzymes have been associated with mitochondrial dysfunction (2,42-45). Vlodavsky et al (46) postulated that post-traumatic cytotoxic edema is associated with mitochondrial function. Sun et al $(47,48)$ found that taurine increases respiratory chain complex activity and mitochondrial-mediated apoptosis and necrosis, and reduces free radical and oxidative stress.

The proapoptotic marker bcl-2 has been shown to increase following brain injury in response to increased oxidants, and apoptosis has been shown to be induced due to increased levels of oxidants and misfolded proteins. In this study, we investigated the expression of various anti-apoptotic markers including p53, caspase-3, and bax. Taurine supplementation substantially reduced expression of these markers in vitro Several studies have reported that taurine is effective against calcium overload and oxidative stress (41). Lotocki et al (18) indicated that inflammation is a well-known critical event in $\mathrm{TBI}$, and inflammation may be induced by the secretion of cytokines and activation of glial cells. Taurine supplementation has been shown to reduce inflammatory cytokines such as TNF- $\alpha$, IL-6, IL- $1 \alpha$, and IL-1 $\beta$ in spinal cord injury and TBI (48). In this study, taurine significantly reduced TNF- $\alpha$ and IL-6 levels.

Taurine supplementation was found to be effective against oxidative stress, apoptosis, and inflammation in injured brain cells.

\section{Acknowledgements}

The present study was supported by the Key Research and Development Project of Shaanxi Province (grant no. 2017SF-180).

\section{Funding}

No funding was received.

\section{Availability of data and material}

The datasets used and/or analyzed during the current study are available from the corresponding author on reasonable request.

\section{Authors' contributions}

XN, SZ, HL and SL were involved in the experimental design, data acquisition, data analysis and interpretation, and manuscript preparation. XN performed the experiments and SZ performed the review of the literature. HL conducted data analysis and SL was a major contributor in writing the manuscript. All authors read and approved the final manuscript.

\section{Ethics approval and consent to participate}

All experiments involving rats were monitored and approved by the Ethics Committee of The Second Affiliated Hospital of Xi'an Jiaotong University (reference no. 2014/2Tx1221).

\section{Patient consent for publication}

Not applicable.

\section{Competing interests}

The authors declare that they have no competing interests.

\section{References}

1. Schuller-Levis GB and Park E: Taurine: New implications for an old amino acid. FEMS Microbiol Lett 226: 195-202, 2003.

2. Wang Q, Fan W, Cai Y, Wu Q, Mo L, Huang Z and Huang H: Protective effects of taurine in traumatic brain injury via mitochondria and cerebral blood flow. Amino Acids 48: 2169-2177, 2016.

3. Huxtable RJ: Physiological actions of taurine. Physiol Rev 72: 101-163, 1992.

4. Rak K, Völker J, Jürgens L, Scherzad A, Schendzielorz P, Radeloff A, Jablonka S, Mlynski R and Hagen R: Neurotrophic effects of taurine on spiral ganglion neurons in vitro. Neuroreport 25: 1250-1254, 2014.

5. Zhang M, Izumi I, Kagamimori S, Sokejima S, Yamagami T, Liu Z and Qi B: Role of taurine supplementation to prevent exercise-induced oxidative stress in healthy young men. Amino Acids 26: 203-207, 2004

6. Yanagita T, Han SY, Hu Y, Nagao K, Kitajima H and Murakami S: Taurine reduces the secretion of apolipoprotein B100 and lipids in HepG2 cells. Lipids Health Dis 7: 38, 2008.

7. Olive MF: Interactions between taurine and ethanol in the central nervous system. Amino Acids 23: 345-357, 2002

8. Dominy J Jr, Thinschmidt JS, Peris J, Dawson R Jr and Papke RL: Taurine-induced long-lasting potentiation in the rat hippocampus shows a partial dissociation from total hippocampal taurine content and independence from activation of known taurine transporters. J Neurochem 89: 1195-1205, 2004.

9. Tsuboyama-Kasaoka N, Shozawa C, Sano K, Kamei Y, Kasaoka S, Hosokawa Y and Ezaki O: Taurine (2-aminoethanesulfonic acid) deficiency creates a vicious circle promoting obesity. Endocrinology 147: 3276-3284, 2006.

10. Birdsall TC: Therapeutic applications of taurine. Altern Med Rev 3: 128-136, 1998.

11. Foos TM and Wu JY: The role of taurine in the central nervous system and the modulation of intracellular calcium homeostasis. Neurochem Res 27: 21-26, 2002.

12. Leon R, Wu H, Jin Y, Wei J, Buddhala C, Prentice H and Wu JY: Protective function of taurine in glutamate-induced apoptosis in cultured neurons. J Neurosci Res 87: 1185-1194, 2009.

13. El Idrissi A, Messing J, Scalia J and Trenkner E: Prevention of epileptic seizures by taurine. Adv Exp Med Biol 526: 515-525, 2003. 
14. Maas AI, Stocchetti N and Bullock R: Moderate and severe traumatic brain injury in adults. Lancet Neurol 7: 728-741, 2008.

15. Collins C and Dean J: Acquired brain injury. In: Occupational Therapy and Physical Dysfunction: Principles, Skills and Practice. Turner A, Foster M and Johnson SE (eds). Churchil Livingstone, Edinburgh, pp395-396, 1996.

16. McIntosh TK: Neurochemical sequelae of traumatic brain injury: Therapeutic implications. Cerebrovasc Brain Metab Rev 6 : 109-162, 1994

17. Werner $\mathrm{C}$ and Engelhard K: Pathophysiology of traumatic brain injury. Br J Anaesth 99: 4-9, 2007.

18. Lotocki G, de Rivero Vaccari JP, Perez ER, Sanchez-Molano J, Furones-Alonso O, Bramlett HM and Dietrich WD: Alterations in blood-brain barrier permeability to large and small molecules and leukocyte accumulation after traumatic brain injury: Effects of post-traumatic hypothermia. J Neurotrauma 26: 1123-1134, 2009.

19. Nakajima Y, Osuka K, Seki Y, Gupta RC, Hara M, Takayasu M and Wakabayashi T: Taurine reduces inflammatory responses after spinal cord injury. J Neurotrauma 27: 403-410, 2010.

20. Heidari R, Jamshidzadeh A, Niknahad H, Mardani E, Ommati MM, Azarpira N, Khodaei F, Zarei A, Ayarzadeh M, Mousavi S, et al: Effect of taurine on chronic and acute liver injury: Focus on blood and brain ammonia. Toxicol Rep 3: 870-879, 2016

21. Wang X, Jung J, Fini ME and Lo EH: Mechanical injury in rat cortical cultures activates MAPK signaling pathways and induces secretion of matrix metalloproteinase-2 and -9. J Cereb Blood Flow Metab 21: S264, 2001

22. Katano H, Fulita K, Kato T, Asai K, Kawamura Y, Masago A and Yamada K: Traumatic injury in vitro induces IEG mRNA in cultured glial cells, suppressed by co-culture with neurons. Neuroreport 10: 2439-2448, 1999.

23. Lau LT and Yu AC: Astrocytes produce and release interleukin-1, interleukin-6, tumor necrosis factor alpha and interferon-gamma following traumatic and metabolic injury. J Neurotrauma 18 : $351-359,2001$

24. Kaddour T, Omar K, Oussama AT, Nouria H, Iméne B and Abdelkader A: Aluminium-induced acute neurotoxicity in rats: Treatment with aqueous extract of Arthrophytum (Hammada scoparia). J Acute Dis 5: 470-482, 2016.

25. Erden Inal M, Akgün A and Kahraman A: The effects of exogenous glutathione on reduced glutathione level, glutathione peroxidase and glutathione reductase activities of rats with different ages and gender after whole-body $\Gamma$-irradiation. J Am Aging Assoc 26: 55-58, 2003.

26. Madakkannu B and Ravichandran R: In vivo immunoprotective role of Indigofera tinctoria and Scoparia dulcis aqueous extracts against chronic noise stress induced immune abnormalities in Wistar albino rats. Toxicol Rep 4: 484-493, 2017.

27. AfshariJT,GhomianN,Shameli A,ShakeriMT,FahmidehkarMA, Mahajer E, Khoshnavaz R and Emadzadeh M: Determination of interleukin-6 and tumor necrosis factor-alpha concentrations in Iranian-Khorasanian patients with preeclampsia. BMC Pregnancy Childbirth 5: 14, 2005.

28. Medhat D, Hussein J, El-Naggar ME, Attia MF, Anwar M Latif YA, Booles HF, Morsy S, Farrag AR, Khalil WKB and El-Khayat Z: Effect of Au-dextran NPs as anti-tumor agent against EAC and solid tumor in mice by biochemical evaluations and histopathological investigations. Biomed Pharmacother 91: 1006-1016, 2017

29. Shaheen TI, El-Naggar MI, Hussein JS, El-Bana M, Emara E, El-Khayat Z, Fouda MMG, Ebaid H and Hebeish A: Antidiabetic assessment; in vivo study of gold and core-shell silver-gold nanoparticles on streptozotocin-induced diabetic rats. Biomed Pharmacother 83: 865-875, 2016.
30. Livak KJ and Schmittgen TD: Analysis of relative gene expression data using real-time quantitative PCR and the 2(-Delta Delta C(T)) method. Methods 25: 402-408, 2001.

31. Lobos E, Gebhardt C, Kluge A and Spanel-Borowski K: Expression of nerve growth factor (NGF) isoforms in the rat uterus during pregnancy: Accumulation of precursor proNGF. Endocrinology 146: 1922-1929, 2005.

32. Sun M, Zhao Y, Gu Y and Xu C: Anti-inflammatory mechanism of taurine against ischemic stroke is related to down-regulation of PARP and NF- $\kappa$ B. Amino Acids 42: 1735-1747, 2012.

33. Yang Y, Zhang Y, Liu X, Zuo J, Wang K, Liu W and Ge J: Exogenous Taurine attenuates mitochondrial oxidative stress and endoplasmic reticulum stress in rat cardiomyocytes. Acta Biochim Biophys Sin (Shanghai) 45: 359-367, 2013.

34. Sun M, Zhao Y, Gu Y and Zhang Y: Protective effects of taurine against closed head injury in rats. J Neurotrauma 32: 66-74, 2015.

35. Schaffer SW, Jong CJ, Ito T and Azuma J: Effect of taurine on ischemia-reperfusion injury. Amino Acids 46: 21-30, 2014.

36. Shimada K, Jong CJ, Takahashi K and Schaffer SW: Role of ROS production and turnover in the antioxidant activity of taurine. Adv Exp Med Biol 803: 581-596, 2015.

37. Chen $\mathrm{H}$ and Chan DC: Mitochondrial dynamics-fusion, fission, movement, and mitophagy-in neurodegenerative diseases. Hum Mol Genet 18: 169-176, 2009

38. Xiong Y, Gu Q, Peterson PL, Muizelaar JP and Lee CP: Mitochondrial dysfunction and calcium perturbation induced by traumatic brain injury. J Neurotrauma 14: 23-34, 1997.

39. Keelan J, Timothy EB and Clark BJ: Heightened resistance of the neonatal brain to ischemia-reperfusion involves a lack of mitochondrial damage in the nerve terminal. Brain Res 821: 124-133, 1999.

40. Zhu KJ, Huang $\mathrm{H}$, Chu $\mathrm{H}$, Yu $\mathrm{H}$ and Zhang SM: Alterations in enterocyte mitochondrial respiratory function and enzyme activities in gastrointestinal dysfunction following brain injury. World J Gastroenterol 20: 9585-9591, 2014.

41. Prentice H, Modi JP and Wu JY: Mechanisms of neuronal protection against excitotoxicity, endoplasmic reticulum stress, and mitochondrial dysfunction in stroke and neurodegenerative diseases. Oxid Med Cell Longev 2015: 964518, 2015.

42. Gong H, Li H, Li J and Wang C: Myricetin inhibition on murine glioma GL261 cell line. Farmacia 65: 1-7, 2017.

43. Tătăranu LG, Georgescu AM, Buteică SA, Siloși I, Mogosanu GD, Purcaru SO, Alexandru O, Stovicek' OP, Brîndưșa C, Doșa M, et al: Ligustrum vulgare hydroalcoholic extract induces apoptotic cell death in human primary brain tumour cells. Farmacia 65: 766-771, 2017.

44. Boda D, Negrei C, Nicolescu F and Bălălău C: Assessment of some oxidative stress parameters in methotrexate treated psoriasis patients. Farmacia 62: 704-710, 2014.

45. Negrei C, Arsene AL, Toderescu CD, Boda D and Ilie M: Acitretin treatment in psoriazis may influence the cell membrane fluidity. Farmacia 60: 767-772, 2012

46. Vlodavsky E, Palzur E, Shehadeh M and Soustiel JF: Posttraumatic cytotoxic edema is directly related to mitochondrial function. J Cereb Blood Flow Metab 37: 166-177, 2017.

47. Sun M, Gu Y, Zhao Y and Xu C: Protective functions of taurine against experimental stroke through depressing mitochondria-mediated cell death in rats. Amino Acids 40: 1419-1429, 2011.

48. Sun Q, Hu H, Wang W, Jin H, Feng G and Jia N: Taurine attenuates amyloid $\beta 1-42$-induced mitochondrial dysfunction by activating of SIRT1 in SK-N-SH cells. Biochem Biophys Res Commun 447: 485-489, 2014.

This work is licensed under a Creative Commons Attribution-NonCommercial-NoDerivatives 4.0 International (CC BY-NC-ND 4.0) License. 